\title{
Phytoextraction, phytotransformation and rhizodegradation of ibuprofen associated with Typha angustifolia in a horizontal subsurface flow constructed wetland
}

\author{
Yifei Li ${ }^{\text {a, b, * , Jiefeng Zhang }}{ }^{\text {a, c }}$, Guibing Zhu ${ }^{\text {d, }{ }^{* *}}$, Yu Liu ${ }^{\text {a, b }}$, Bing Wu ${ }^{\text {e }}$, Wun Jern Ng ${ }^{\text {a, c }}$, \\ Adhityan Appan ${ }^{\mathrm{c}}$, Soon Keat Tan ${ }^{\mathrm{a}, \mathrm{c}, \mathrm{f}}$ \\ a School of Civil and Environmental Engineering, Nanyang Technological University, 50 Nanyang Avenue, 639798, Singapore \\ ${ }^{\mathrm{b}}$ Advanced Environmental Biotechnology Centre, Nanyang Environment and Water Research Institute, Nanyang Technological University, 1 Cleantech Loop, \\ CleanTech One, 637141, Singapore \\ ${ }^{\mathrm{c}}$ Nanyang Environment and Water Research Institute, Nanyang Technological University, 1 Cleantech Loop, CleanTech One, 637141, Singapore \\ d Key Laboratory of Drinking Water Science and Technology, Research Center for Eco-Environmental Sciences, Chinese Academy of Sciences, Beijing, 100085, \\ PR China \\ e Singapore Membrane Technology Centre, Nanyang Environment and Water Research Institute, Nanyang Technological University, 1 Cleantech Loop, \\ CleanTech One, 637141, Singapore \\ ${ }^{\mathrm{f}}$ Maritime Research Centre, Nanyang Technological University, 50 Nanyang Avenue, 639798, Singapore
}

\section{A R T I C L E I N F O}

\section{Article history:}

Received 4 May 2016

Received in revised form

23 June 2016

Accepted 24 June 2016

Available online 25 June 2016

\section{Keywords:}

Organic micropollutant

Non-steroidal anti-inflammatory drug

Phytoremediation

Macrophyte

Microorganism

\begin{abstract}
A B S T R A C T
Widespread occurrence of trace pharmaceutical residues in aquatic environments is of great concerns due to the potential chronic toxicity of certain pharmaceuticals including ibuprofen on aquatic organisms even at environmental levels. In this study, the phytoextraction, phytotransformation and rhizodegradation of ibuprofen associated with Typha angustifolia were investigated in a horizontal subsurface flow constructed wetland system. The experimental wetland system consisted of a planted bed with Typha angustifolia and an unplanted bed (control) to treat ibuprofen-loaded wastewater $\left(\sim 107.2 \mu \mathrm{g} \mathrm{L}^{-1}\right)$. Over a period of 342 days, ibuprofen was accumulated in leaf sheath and lamina tissues at a mean concentration of $160.7 \mathrm{ng} \mathrm{g}^{-1}$, indicating the occurrence of the phytoextraction of ibuprofen. Root-uptake ibuprofen was partially transformed to ibuprofen carboxylic acid, 2-hydroxy ibuprofen and 1-hydroxy ibuprofen which were found to be $1374.9,235.6$ and $301.5 \mathrm{ng} \mathrm{g}^{-1}$ in the sheath, respectively, while they were $1051.1,693.6$ and $178.7 \mathrm{ng} \mathrm{g}^{-1}$ in the lamina. The findings from pyrosequencing analysis of the rhizosphere bacteria suggest that the Dechloromonas sp., the Clostridium sp. (e.g. Clostridium saccharobutylicum), the order Sphingobacteriales, and the Cytophaga sp. in the order Cytophagales were most probably responsible for the rhizodegradation of ibuprofen.
\end{abstract}

() 2016 Elsevier Ltd. All rights reserved.

\section{Introduction}

Pharmaceutical residues have been frequently observed in various aquatic environments such as wastewater, surface water, ground water and even drinking water (Cizmas et al., 2015; Luo et al., 2014). These compounds, regarded as emerging pollutants, are at trace levels (ng L $\mathrm{L}^{-1}$ to $\mu \mathrm{g} \mathrm{L}^{-1}$ ) in the aquatic environment,

\footnotetext{
* Corresponding author. School of Civil and Environmental Engineering, Nanyang Technological University, 50 Nanyang Avenue, 639798, Singapore.

** Corresponding author.

E-mail addresses: yli19@e.ntu.edu.sg (Y. Li), gbzhu@rcees.ac.cn (G. Zhu).
}

normally at least one order of magnitude lower than the levels to cause acute ecotoxicity (Corcoran et al., 2010). However, the nontarget aquatic organisms including fish have a high probability of suffering unintended direct or side effects induced by such pharmaceuticals that are generally regarded to have a low toxic effect on humans or livestock (Corcoran et al., 2010; Liu et al., 2015). This is perhaps attributed to (1) the biological active nature of some pharmaceuticals in non-target organisms unlike the principal function to the target organisms, especially under long-term exposure resulted by the continuous release of pharmaceuticals into the aquatic environment; and (2) the additive toxic effects of the combinations of various pharmaceuticals and other pollutants (Cizmas et al., 2015; Corcoran et al., 2010; Fent et al., 2006). 
Therefore, developing efficient methods to control pharmaceutical pollution in aquatic environments is of great urgency and significance.

As a secondary wastewater treatment or a wastewater polishing process, constructed wetlands have received increasing attention on their application in treating pharmaceutical-containing wastewaters (Li et al., 2014; Verlicchi and Zambello, 2014). The ecological perspective and economical operation of constructed wetlands make for attractive application alternatives in regions where there are lacking of appropriate infrastructure to set up centralized wastewater treatment plants (WWTPs) (Babatunde et al., 2008; Vymazal, 2011). To date, however, most of the reported work is related to the performance of constructed wetlands for the removal of pharmaceutical contaminants. There has not been a comprehensive understanding of the relevant mechanisms involving the substrate, plants and microorganisms of constructed wetlands. In particular, there are large gaps on the plant-associated mechanisms in constructed wetlands such as phytoextraction (uptake, translocation and accumulation), phytotransformation (degradation in plant tissues) and rhizodegradation (microbial degradation in rhizosphere) for the removal of pharmaceuticals from wastewater.

This study selected ibuprofen as the target pharmaceutical, a non-steroidal anti-inflammatory drug (Corcoran et al., 2010; Flippin et al., 2007). Ibuprofen is one of the most widely used over-the-counter drugs and is one of the most frequently detected pharmaceuticals in aquatic environments such as raw wastewaters, effluents of WWTPs and surface waters (Corcoran et al., 2010; Luo et al., 2014; Saravanan et al., 2012). It has been reported that ibuprofen is toxic to reproduction of some aquatic organisms, for example, changing the spawning pattern of Medaka at environmental concentrations of $1-100 \mu \mathrm{g} \mathrm{L}^{-1}$ (Flippin et al., 2007), eliciting embryo abnormalities of zebrafish if at a concentration higher than $10 \mu \mathrm{g} \mathrm{L}^{-1}$ (David and Pancharatna, 2009), and altering egg hatching of Daphnia magna at a concentration range of 0.5-50 $\mu \mathrm{g} \mathrm{L}^{-1}$ (Wang et al., 2016).

The objective of this study was to assess the phytoextraction, phytotransformation and rhizodegradation of ibuprofen associated with the macrophyte Typha angustifolia in constructed wetlands. For this purpose, a mesocosm-scale horizontal subsurface flow constructed wetland system was constructed for the treatment of ibuprofen-loaded wastewater. The system consisted of a planted bed with Typha angustifolia and an unplanted bed as the control. The concentrations of ibuprofen and three of its metabolites including ibuprofen carboxylic acid, 2-hydroxy ibuprofen and 1hydroxy ibuprofen in the water samples and the leaf tissues (sheath and lamina) were tested to evaluate the mechanisms of phytoextraction and phytotransformation. The bacterial DNA templates were periodically isolated from the rhizosphere samples for 454 high-throughput pyrosequencing analysis to identify the bacteria responsible for the rhizodegradation of ibuprofen.

\section{Materials and methods}

\subsection{Chemicals}

The chemicals used in this study included the followings. Glucose (anhydrous), ammonium sulfate (99+\%), potassium dihydrogen phosphate (98+\%), magnesium sulfate heptahydrate (99+\%), calcium chloride dihydrate (99-105\%), sodium hydrogen carbonate $(99 \%)$ and sodium carbonate $(98 \%)$ were acquired from Alfa Aesar (USA) and were used for the synthesis of municipal wastewater. High purity $(\geq 98 \%)$ ibuprofen (IBP), 2-hydroxy ibuprofen (2-OH IBP), 1-hydroxy ibuprofen (1-OH IBP) and ibuprofen- $\mathrm{d}_{3}\left(\right.$ IBP- $\left.\mathrm{d}_{3}\right)$ were supplied by Sigma-Aldrich (USA). High purity ( $\geq 98 \%$ ) ibuprofen carboxylic acid (CBX IBP) was provided by
Toronto Research Chemicals (Canada). HPLC-grade methanol, $n$ hexane, hydrochloric acid (37\%) and ammonium acetate $5 \mathrm{M}$ solution were acquired from Merck (USA).

\subsection{Experimental wetland system}

A mesocosm-scale horizontal subsurface flow constructed wetland (HSSF-CW) system was set up at Nanyang Technological University (NTU) campus in Singapore under tropical climate. The system was installed in a semi-sheltered environment with a transparent roof and insect nettings on all sides. The system consisted of a 200-L wastewater holding tank and two identical fiberglass HSSF-CW beds (Fig. 1). One bed was planted with Typha angustifolia (initial density: 15 plants $\mathrm{m}^{-2}$ ), and the other was unplanted (control). Both beds were packed with a $300 \mathrm{~mm}$ deep gravel layer containing rough gravels (size of $20-24 \mathrm{~mm}$ ) at the inlet and outlet sections and fine gravels (size of $4-10 \mathrm{~mm}$ ) at the treatment section. The influent was pumped from the wastewater holding tank to the surface of the inlet section to ensure $250 \mathrm{~mm}$ deep water below the gravel surface. Two perforated pipes $(20 \mathrm{~mm}$ i.d.) were installed vertically into the gravel to collect interstitial water at the one-third length $(1 / 3 \mathrm{~L})$ and two-third length $(2 / 3 \mathrm{~L})$ of the treatment section along the flow path. The treatment section was divided accordingly into three zones: upstream $1 / 3$ zone (inlet to $1 / 3 \mathrm{~L}$ ), middle $1 / 3$ zone ( $1 / 3 \mathrm{~L}$ to $2 / 3 \mathrm{~L}$ ) and downstream $1 / 3$ zone (2/3L to outlet). The two sampling pipes also worked as ventilation pipes to enhance the aeration process in the beds to some degree.

\subsection{System operation and sampling}

After the Typha angustifolia was acclimated in the planted bed, the HSSF-CW system was fed continuously with IBP-free synthetic wastewater at the rate $\left(7.64 \mathrm{~mL} \mathrm{~min}^{-1}\right)$ equivalent to a 4-day hydraulic retention time. The synthetic wastewater was designed to contain $300 \mathrm{mg} \mathrm{L}^{-1}$ of chemical oxygen demand (COD), $27 \mathrm{mg} \mathrm{L}^{-1}$ of ammonium nitrogen $\left(\mathrm{NH}_{4}^{+}-\mathrm{N}\right)$ and $18 \mathrm{mg} \mathrm{L}^{-1}$ of total phosphate (TP). From the $30^{\text {th }}$ day onwards, the influent water was spiked with IBP $\left(\sim 100 \mu \mathrm{g} \mathrm{L}^{-1}\right)$. It has been reported that the IBP concentration ranged from $<0.004$ to $603 \mu \mathrm{g} \mathrm{L}^{-1}$ in the influent wastewater of conventional WWTPs (Luo et al., 2014). To clearly elucidate IBP transportation pathway associated with the plants in wetland, a relatively high concentration of IBP $\left(\sim 100 \mu \mathrm{g} \mathrm{L}^{-1}\right)$ was used in this study. The sampling campaign commenced on the $30^{\text {th }}$ day at four sampling locations in each bed: inlet, $1 / 3 \mathrm{~L}, 2 / 3 \mathrm{~L}$ and outlet. A $40 \mathrm{~mL}$ of water sample was collected from each location every 4 days to test certain water-quality parameters: temperature, $\mathrm{pH}$, dissolved oxygen (DO), oxidation reduction potential (ORP), $\mathrm{COD}, \mathrm{NH}_{4}^{+}-\mathrm{N}$ and TP. After the system had adapted to the IBP injection (about 30 days), from the 62nd day onwards, the sampling interval was changed to once every 8 days. An additional $50 \mathrm{~mL}$ of water sample was collected from each location to monitor the concentrations of IBP and its metabolites (CBX IBP, 2-OH IBP and 1-OH IBP). Besides, every 8 days, one or two entire leaves of Typha angustifolia were randomly collected at $1 / 3 \mathrm{~L}$ and $2 / 3 \mathrm{~L}$, respectively. The leaf samples were separated into lamina (the blade part of leaf) and sheath (the basal part of leaf) tissues and the concentrations of IBP and its metabolites inside these tissues were measured. The system was continuously operated over a long-term period of 342 days. From the 62nd day onwards, the rhizosphere samples (sediment mixture) near plant roots at $1 / 3 \mathrm{~L}$ and $2 / 3 \mathrm{~L}$ were collected using peristaltic pump, respectively, in five sampling periods with an interval of 40 days. In each period that lasted 24 days, rhizosphere samples (50 mL each) were collected every eight days (including the initial day) and the total four samples at each location were mixed as a composite sample for bacterial DNA extraction. In the 


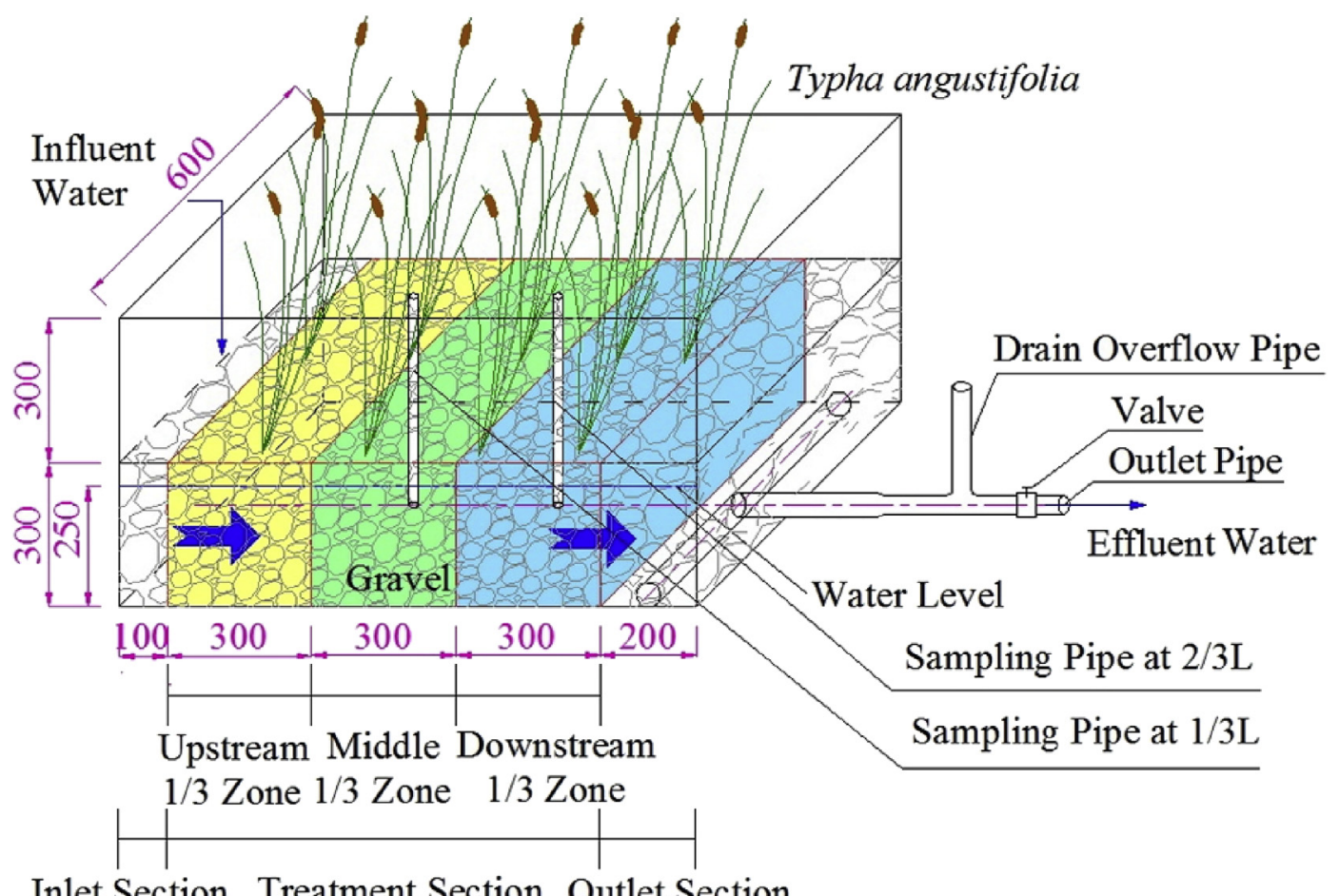

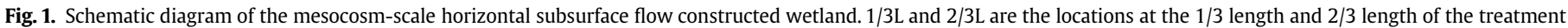
section along the flow path, respectively. Unit: $\mathrm{mm}$.

rhizosphere samples, the interstitial water with suspended detached biofilms accounted for more than $90 \%$ in comparison to the sediments (silt and plant residues).

\subsection{Analytical testing methods for water-quality parameters}

Temperature, pH, DO and ORP of the water samples were measured on site using an HQ40d Portable Multi-parameter Meter (Hach, USA). COD, $\mathrm{NH}_{4}^{+}-\mathrm{N}$ and TP were determined by the COD Digestion Solution Kit (Hach, USA), the AmVer ${ }^{\text {TM }}$ High Range Ammonia Reagent Set (Hach, USA), and the High-range Total Phosphate Reagent Set (Hach, USA), respectively. The analytical instruments were the DRB200 digital reactor block and the DR $3800^{\mathrm{TM}}$ benchtop spectrophotometer (Hach, USA).

\subsection{Solid phase extraction (SPE)}

The water samples ( $50 \mathrm{~mL}$ each) for the analysis of IBP and its metabolites were vacuum percolated through $1.2 \mu \mathrm{m}$ glass microfibre filters (Cole-Parmer, USA) and $0.45 \mu \mathrm{m}$ nylon membrane filters (Phenomenex, USA) and acidified to $\mathrm{pH} 2$ with hydrochloric acid. The samples were then pre-concentrated with Phenomenex Strata$\mathrm{X}$ (60 mg, $3 \mathrm{~mL}$, USA) SPE cartridges for solid phase extraction (SPE). The cartridges were conditioned with $5 \mathrm{~mL}$ of methanol followed by $5 \mathrm{~mL}$ of $\mathrm{pH} 2$ Milli-Q water $\left(1 \mathrm{~mL} \mathrm{~min}{ }^{-1}\right)$ and thereafter the samples were vacuum percolated through the cartridges $\left(3 \mathrm{~mL} \mathrm{~min}{ }^{-1}\right)$. The sample-loaded cartridges were rinsed with $5 \mathrm{~mL}$ of Milli-Q water and vacuum dried for $30 \mathrm{~min}$. The elution was performed with $5 \mathrm{~mL}$ of methanol $\left(1 \mathrm{~mL} \mathrm{~min}^{-1}\right)$ and the extract was filtered through $0.45 \mu \mathrm{m}$ PTFE membrane filter (Filtrex, Singapore).

\subsection{Sea sand disruption method (SSDM)}

The extraction of IBP and its metabolites from the plant leaves was performed using the sea sand disruption method (SSDM) (Dordio et al., 2011). The leaf samples (lamina and sheath tissues) were preliminarily rinsed with $1 \mathrm{M}$ hydrochloric acid followed by three rinses with Milli-Q water. The sea sand was washed several times with Milli-Q water followed by three times of rinsing with methanol. Both the cleansed leaf samples and sea sand were air dried in the laboratory (about 7 days). Thereafter, $0.5 \mathrm{~g}$ of dried leaf samples was placed in a mortar with $2 \mathrm{~g}$ of sea sand and $4 \mathrm{~mL}$ of $n$ hexane. The materials were ground in the cleaned mortar with a pestle. The blend was then transferred into a $10 \mathrm{~mL}$ syringe connected to a $0.45 \mu \mathrm{m}$ PTFE membrane filter (Filtrex, Singapore). The syringe was vacuum dried for $30 \mathrm{~min}$ and then eluted with $10 \mathrm{~mL}$ of methanol. The extract gotten from the syringe was evaporated under gentle nitrogen stream and reconstituted with $5 \mathrm{~mL}$ of methanol. In this study, the concentration of IBP or its metabolites in the leaf tissue was calculated based on the dry weight of leaf tissue $\left(\mathrm{ng} \mathrm{g}^{-1}\right)$.

\subsection{Liquid chromatography-tandem mass spectrometry (LC-MS/ MS)}

Chromatographic separation of the target compounds was carried out at room temperature $\left(23 \pm 1^{\circ} \mathrm{C}\right)$ with a Shimadzu liquid chromatography instrument (Japan) equipped with a DGU-20A degasser, two LC-20AD pumps, a SIL-20AHT autosampler, a CBM$20 \mathrm{~A}$ controller and a CTO-20AC column oven, using a Luna C18 (2) reversed phase column ( $75 \mathrm{~mm} \times 2 \mathrm{~mm}, 3 \mu \mathrm{m}$ particle size) and a C18 security guard cartridge ( $4 \mathrm{~mm} \times 2 \mathrm{~mm}$ ) (Phenomenex, USA). A binary mobile phase of $5 \mathrm{mM}$ ammonium acetate $(A)$ and methanol (B) was used at a flow rate of $0.2 \mathrm{~mL} \mathrm{~min}^{-1}$. The program of the gradient elution was: $0-0.5 \mathrm{~min}, 5 \%-65 \% \mathrm{~B}$; $0.5-6.0 \mathrm{~min}$, $65 \%-95 \% \mathrm{~B} ; 6.0-6.1 \mathrm{~min}, 95 \%-100 \% \mathrm{~B} ; 6.1-7.0 \mathrm{~min}, 100 \% \mathrm{~B}$; 7.0-7.1 $\mathrm{min}, 100 \%-5 \% \mathrm{~B} ; 7.1-10.0 \mathrm{~min}, 5 \%$ B. Sample injection volume was $10 \mu \mathrm{L}$. The liquid chromatography instrument was 
coupled to a LCMS-8030 triple quadrupole mass spectrometer (Shimadzu, Japan). Detection was performed in either positive or negative mode by multiple reaction monitoring (MRM).

Quantification of the analytes (IBP, CBX IBP, 2-OH IBP and 1-OH IBP) in the extract from SPE and SSDM was performed using an internal standard method that was established with a series of calibration standard solutions of analytes $(1000,500,100,50,10,5$ and $\left.1 \mu \mathrm{g} \mathrm{L}^{-1}\right)$. IBP-d $3\left(10 \mathrm{mg} \mathrm{L}^{-1}, 10 \mu \mathrm{L}\right.$ ) solution was mixed with each standard solution $(1 \mathrm{~mL})$ for internal standard calibration $\left(100 \mu \mathrm{g} \mathrm{L}^{-1}\right)$. The linearity and limit of the LC-MS/MS method are shown in Table S1. Extracted ion chromatograms of a standard mixture of analytes at $100 \mu \mathrm{g} \mathrm{L}^{-1}$ are shown in Fig. S1. CBX IBP was confirmed by the fragment ion 191.10. For IBP confirmation, fragment ion 161.15 was taken into account. Although 2-OH IBP and 1OH IBP share the same MRM transition $(240.30>205.10)$, they can be distinguished according to their different retention times. Recoveries of the SPE-LC-MS/MS method for the target compounds are shown in Table S1. Recoveries of the SSDM-LC-MS/MS method for IBP, CBX IBP, 2-OH IBP and 1-OH IBP in the leaf samples were $103.9 \%, 120.6 \%, 111.7 \%$ and $82.6 \%$, respectively (the mean values of those for the leaf lamina and sheath).

\subsection{DNA extraction and pyrosequencing}

The rhizosphere samples (50 $\mathrm{mL}$ each) were centrifuged at $10,000 \mathrm{rpm}$ for $10 \mathrm{~min}$. Genomic DNA templates were then extracted from the deposits according to the protocol of the FastDNA $^{\text {TM }}$ SPIN Kit for Soil (MP Biomedicals, USA). Universal 16S bacterial primers $341 \mathrm{~F}$ and $907 \mathrm{R}$ were used to amplify about $500 \mathrm{bp}$ fragment of 16S rRNA gene which was used for 454 highthroughput pyrosequencing by a Roche 454 GS-FLX + machine at Research and Testing Laboratory (Lubbock, TX, USA). Denoising, chimera checking and operational taxonomic units (OTUs) generation were performed using the Research and Testing Laboratory analysis pipeline. The OTU sequences present throughout the sampling periods were selected to construct the neighbor-joining phylogenetic tree with the related sequences deposited in GenBank using the MEGA5.2 software.

\section{Results}

\subsection{HSSF-CW system performance}

Spatial variations of certain water-quality parameters at the inlet, $1 / 3 \mathrm{~L}, 2 / 3 \mathrm{~L}$ and outlet in the experimental HSSF-CW system during the operation period of 342 days are shown in Table S2. The water temperature was stable $\left(\sim 29.5{ }^{\circ} \mathrm{C}\right)$, while the $\mathrm{pH}$ values exhibited a decreasing trend along the flow path in the planted bed (more significant in front of the outlet ranging from 7.5 to 6.5 ). The DO and ORP measurements reveal a predominant anaerobic environment within the wetland beds.

Performance of the HSSF-CW system during the 342-day operation period was evaluated based on the cumulative removal efficiencies (average and standard deviation values) of IBP, COD, $\mathrm{NH}_{4}^{+}-\mathrm{N}$ and TP along the flow path (i.e. at the $1 / 3 \mathrm{~L}, 2 / 3 \mathrm{~L}$ and outlet) as illustrated in Fig. 2. As can be seen in Fig. 2, the cumulative removal efficiencies of IBP along the flow path in the planted bed, especially at the middle $1 / 3$ zone and downstream $1 / 3$ zone, were significantly higher than those in the unplanted bed $(p<0.05)$. COD was largely removed at the upstream $1 / 3$ zone $(>80 \%)$ in both planted and unplanted beds without a significant difference $(p>0.05)$, but the difference became apparent at the downstream zones $(p<0.05)$. For $\mathrm{NH}_{4}^{+}-\mathrm{N}$ and TP, their cumulative removal efficiencies in the planted bed were much higher compared to the unplanted bed $(p<0.05)$. Such observations indicate that the performance of the HSSF-CW planted with Typha angustifolia was more efficient throughout the experimental period and the plants played a positive role in the removal of target pollutants.

\subsection{Ibuprofen and its metabolites in the water}

Fig. 3 shows the concentrations of IBP and its hydroxylated metabolites (2-OH IBP and 1-OH IBP) in the water at inlet, $1 / 3 \mathrm{~L}, 2 / 3 \mathrm{~L}$ and outlet over the operation period of 342 days. The presence of $2-$ $\mathrm{OH}$ IBP and 1-OH IBP at different sampling locations along the flow path except for the inlet was observed, revealing the occurrence of microbial degradation of IBP in the water. Compared to 1-OH IBP, 2$\mathrm{OH}$ IBP was the predominant hydroxyl isomer. Production of 2-OH IBP in the planted bed showed a significantly higher concentration level $(p<0.05)$ and a more obvious increasing trend along the flow path than that in the unplanted bed. It suggests the positive role of Typha angustifolia in the microbial degradation of IBP in the water. In addition, the ratio of the microbial degradation of IBP with 2-OH IBP production induced by the plants to the total IBP removal in the planted bed was about $12.5 \%$.

As for CBX IBP, the carboxylated metabolite of IBP, its appearance in the water along the flow path during the 342-day wetland operation is presented in Fig. 4. CBX IBP was undetected at the inlet and infrequently observed (quantification limit: $1.38 \mu \mathrm{g} \mathrm{L}^{-1}$ ) at other sampling locations (1/3L, 2/3L and outlet), showing a low concentration level in the range of $2.1-8.0 \mu \mathrm{g} \mathrm{L}^{-1}$ and $2.3-4.2 \mu \mathrm{g} \mathrm{L}^{-1}$ in the planted and unplanted beds, respectively. The more frequent observation of CBX IBP in the planted bed compared to the unplanted bed indicates the promotion of Typha angustifolia to the microbial degradation of IBP in the water.

\subsection{Ibuprofen and its metabolites in the leaf tissues}

The concentrations of IBP and its metabolites (CBX IBP, 2-OH IBP and $1-\mathrm{OH}$ IBP) in the leaf tissues at $1 / 3 \mathrm{~L}$ and $2 / 3 \mathrm{~L}$ over the 342-day operation period are illustrated in Fig. 5. IBP was detected in both lamina and sheath tissues of Typha angustifolia at the two locations, indicating the IBP phytoextraction process, i.e., IBP had been taken up by the roots of Typha angustifolia and translocated from the roots to leaves. The accumulation of IBP in the leaf tissues reveals a generally even distribution at a mean concentration of $160.7 \mathrm{ng} \mathrm{g}^{-1}$, suggesting that there is no significant difference between the IBP transportation in the xylem sap of lamina and sheath tissues $(p>0.05)$.

The presence of CBX IBP, 2-OH IBP and 1-OH IBP in the leaf tissues as shown in Fig. 5 indicates the phytoextraction of IBP metabolites from the surrounding water or/and the phytotransformation of IBP in the plant tissues. In particular, 2-OH IBP was accumulated in the lamina tissues at a concentration (693.6 $\mathrm{ng} \mathrm{g}^{-1}$ ) approximately 3 times that in the sheath tissues $\left(235.6 \mathrm{ng} \mathrm{g}^{-1}\right)(p<0.05)$. Adversely, CBX IBP and 1-OH IBP were accumulated in the sheath tissues at concentrations (1374.9 and $301.5 \mathrm{ng} \mathrm{g}^{-1}$ ) about 1.3 and 1.7 times that in the lamina tissues (1051.1 and $\left.178.7 \mathrm{ng} \mathrm{g}^{-1}\right)(p<0.05)$, respectively.

By converting the concentrations of CBX IBP, 2-OH IBP and 1-OH IBP in the leaf tissues to the corresponding IBP concentrations, the normalized IBP concentrations in the leaf tissues are presented in Fig. 5. There was no significant difference between the normalized IBP concentrations in lamina and sheath tissues at $1 / 3 \mathrm{~L}$ and $2 / 3 \mathrm{~L}$ ( $p>0.05)$. The IBP level accumulated in the leaves of Typha angustifolia through phytoextraction was spatially uniform in the planted bed. 


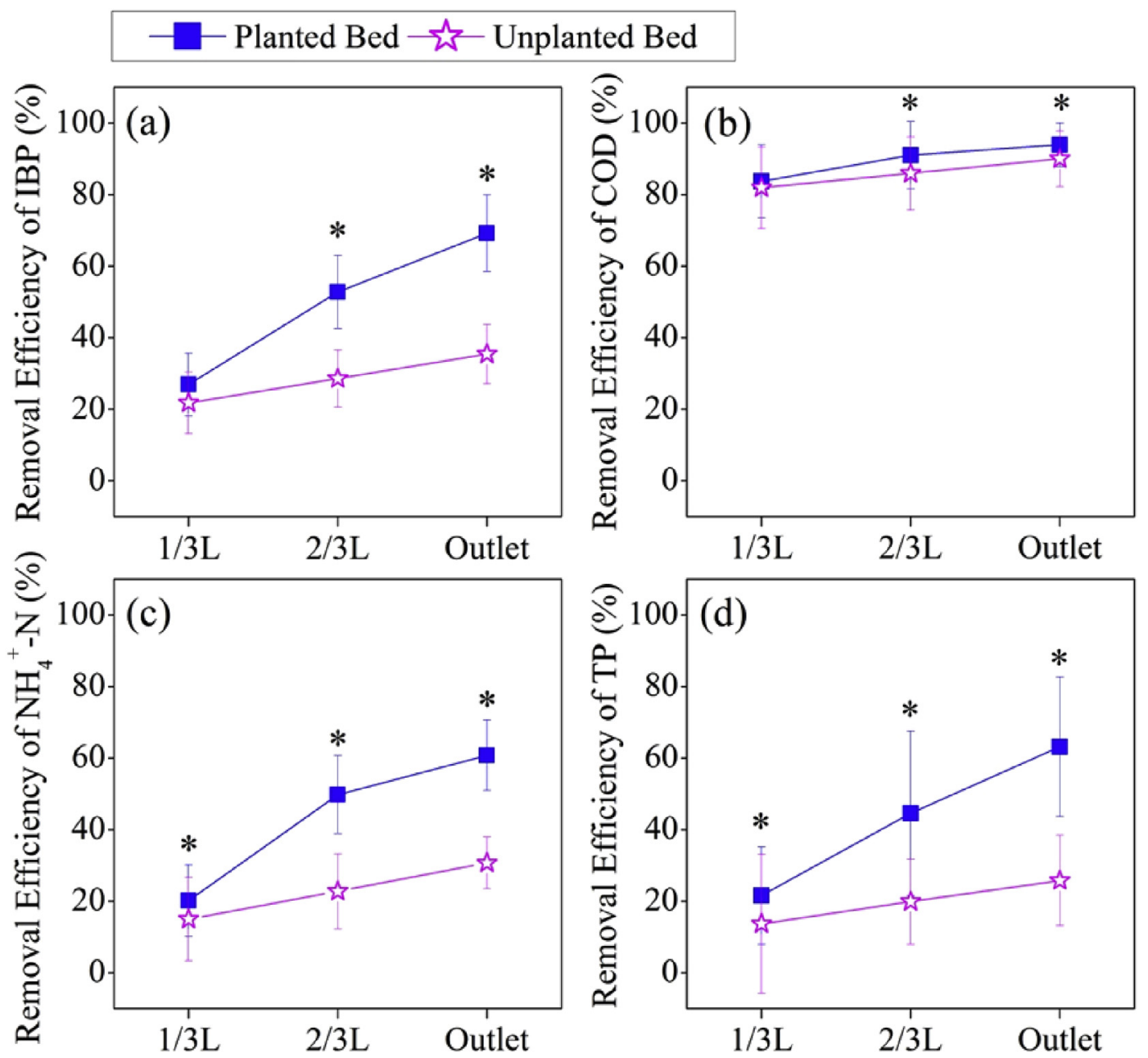

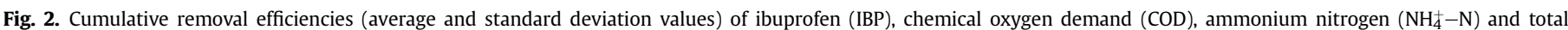

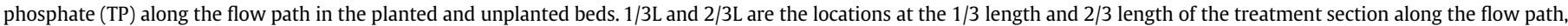
respectively. Sampling campaigns: $n=36$ for IBP, $n=44$ for COD, $\mathrm{NH}_{4}^{+}-\mathrm{N}$ and TP. ${ }^{*}: p<0.05$ ( $t$-test).

\subsection{Phylogenetic analysis of bacteria in the rhizosphere}

In order to gain an insight to the bacteria responsible for the rhizodegradation of IBP in the rhizosphere of Typha angustifolia, pyrosequencing analysis of the bacterial 16S rRNA gene was conducted for the rhizosphere samples of Typha angustifolia. The analysis resulted in a total of 758 OTU sequences of which forty-two OTUs labeled as BAC-HSSFCW-P1 to BAC-HSSFCW-P42 (GenBank accession number: KT950768 to KT950809) were continuously observed throughout the sampling periods. These forty-two OTU sequences were utilized to construct the phylogenetic trees at $1 / 3 \mathrm{~L}$ (Fig. 6) and 2/3L (Fig. 7) and they are affiliated to the phyla of Acidobacteria, Actinobacteria, Bacteroidetes, Chloroflexi, Firmicutes and Proteobacteria.

The bacteria in the rhizosphere of Typha angustifolia associated with the rhizodegradation of IBP were assessed by screening the OTU sequences based on the phylogenetic trees. The continuous removal of IBP along the flow path in the planted bed indicates that the bacteria responsible for the rhizodegradation of IBP were supposed to exist at both sampling locations during all sampling periods. It was found that Thiomonas sp. (BAC-HSSFCW-P2), Thiobacillus thioparus (BAC-HSSFCW-P13), Dechloromonas sp. (BACHSSFCW-P22), Cytophaga sp. (BAC-HSSFCW-P18), Sphingobacteriales (BAC-HSSFCW-P8), Cytophagales (BAC-HSSFCW-P15),
Clostridium sp. (BAC-HSSFCW-P4) and Clostridium saccharobutylicum (BAC-HSSFCW-P24) satisfied the above criteria, which were highlighted in blue in Figs. 6 and 7.

\section{Discussion}

\subsection{Phytoextraction}

Typha angustifolia played a positive role in the performance of HSSF-CW, in consistence with our previous findings (Li and Tan, 2015). The temporal and spatial dynamics of the HSSF-CW system were investigated in this study. Therefore, the root samples of Typha angustifolia were not collected and the direct measurements on the root uptakes of IBP and its metabolites were not performed in order to maintain the continuous operation of the system. The potential of IBP and its metabolites (CBX IBP, 2-OH IBP and 1-OH IBP) taken up by the roots of Typha angustifolia from the interstitial water within the planted bed were assessed by the root concentration factor (RCF). RCF refers to the ratio between the concentration of one specific organic chemical in the root tissue (ng $\mathrm{g}^{-1}$ ) and that in the surrounding external solution $\left(\mu \mathrm{g} \mathrm{L}^{-1}\right)$ under equilibrium conditions (Pilon-Smits, 2005; Trapp, 2004) and can be expressed as Eq. (1) (Trapp, 2004; Trapp and Matthies, 1995). 


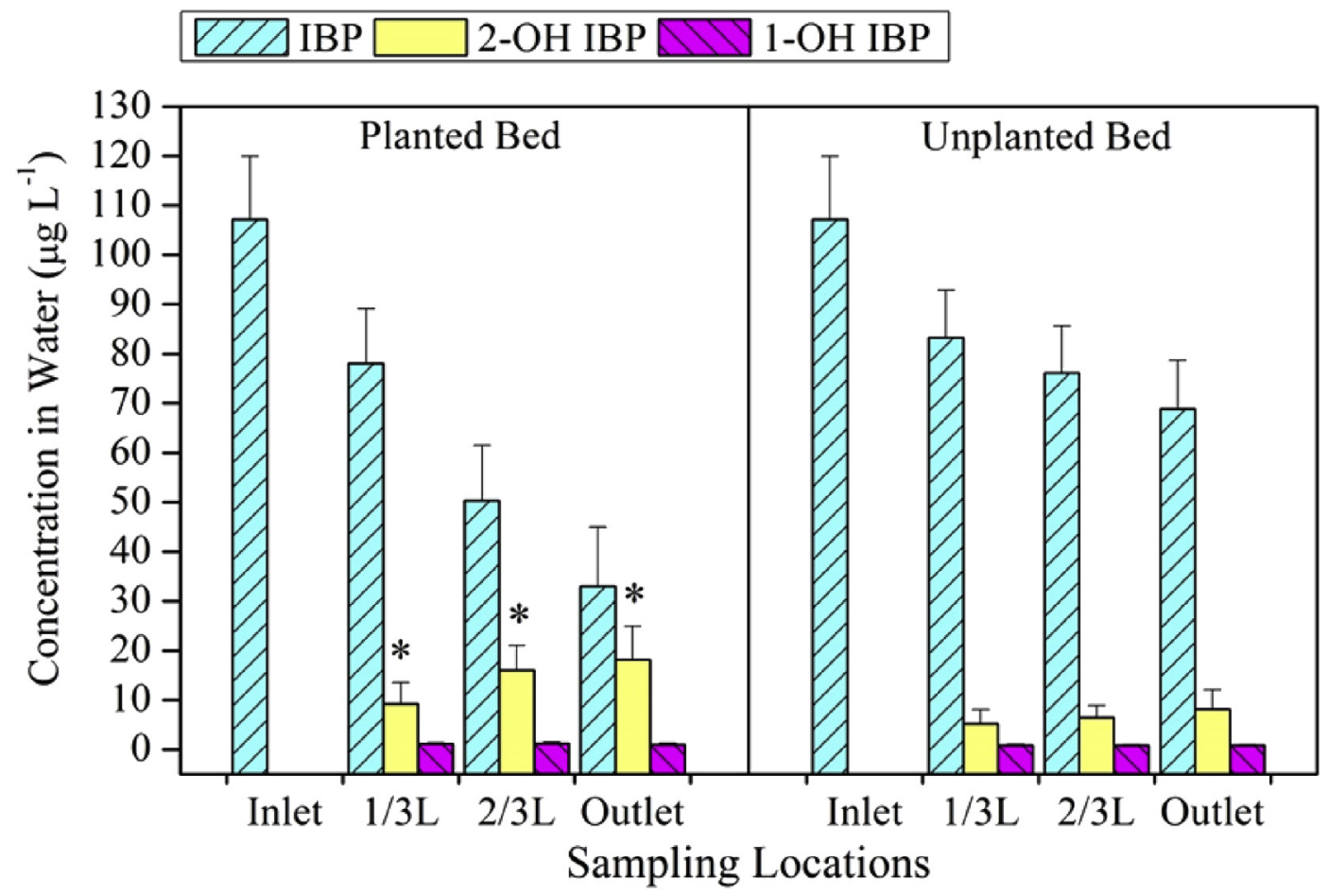

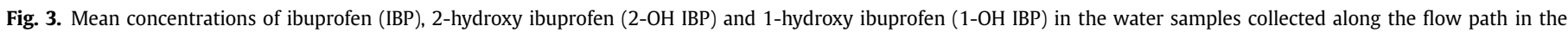

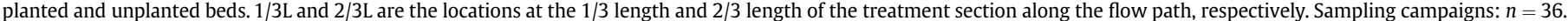
*: $p<0.05$ (t-test). The error bars for the 2-OH IBP concentrations were so small $\left(0.1-0.2 \mu \mathrm{g} \mathrm{L}^{-1}\right)$ that they were difficult to be seen.

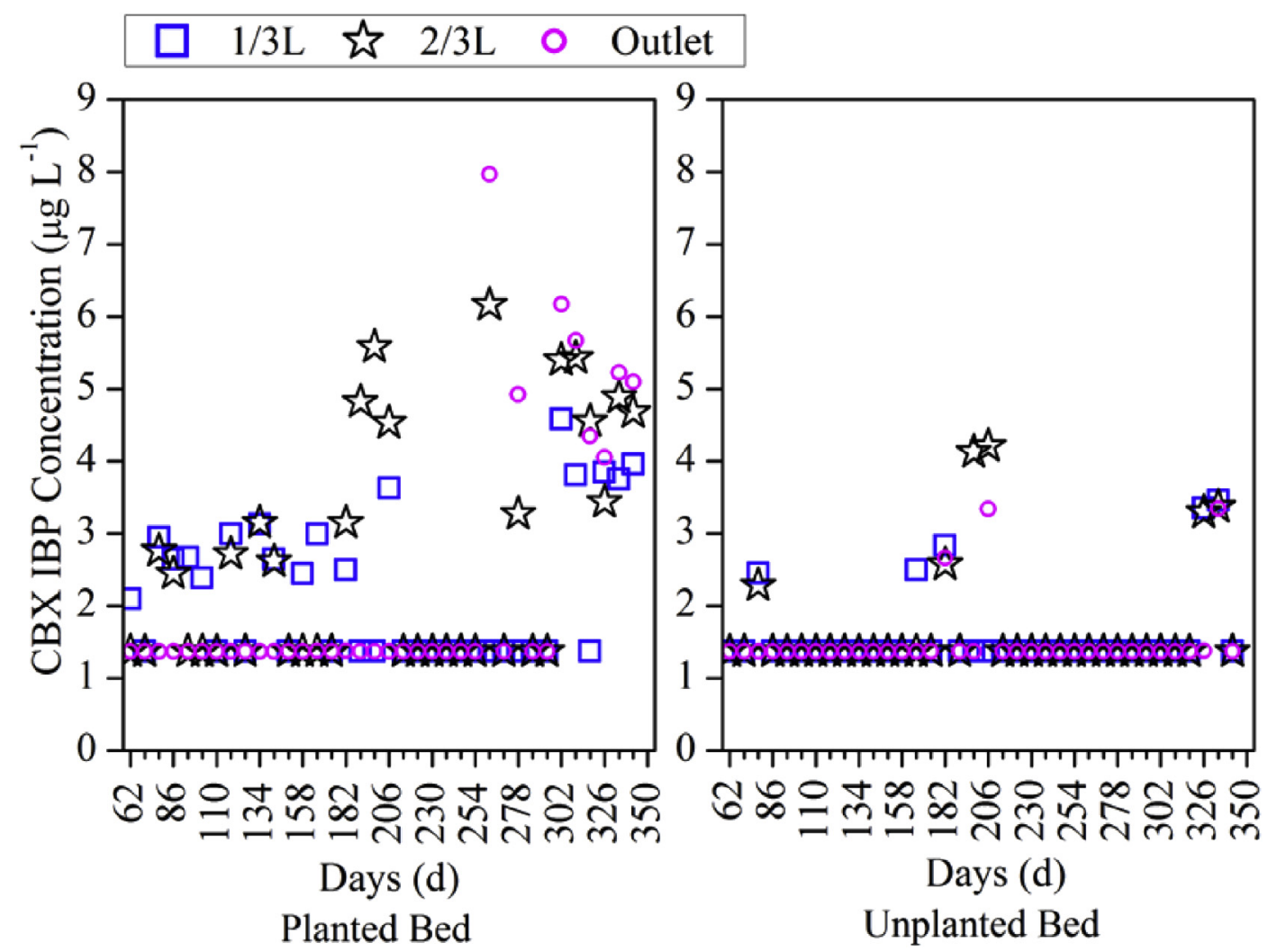

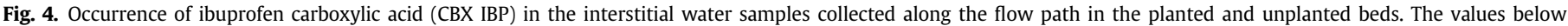

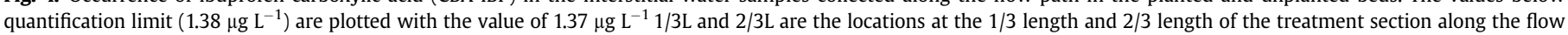
path, respectively. Sampling campaigns: $n=36$. 


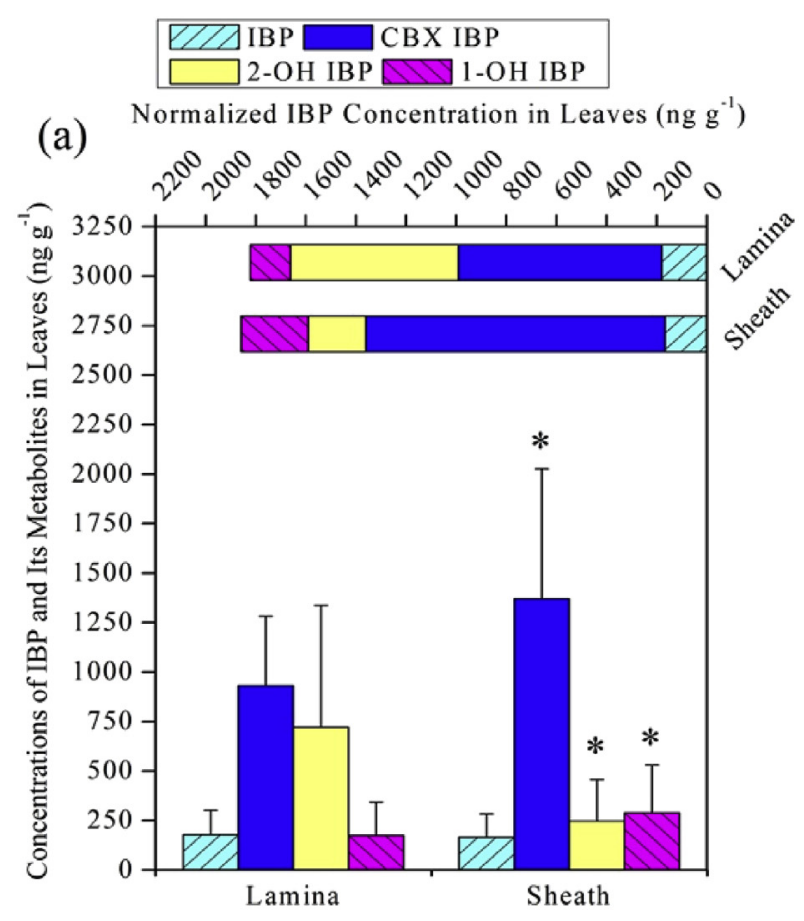

(b) Normalized IBP Concentration in Leaves ( $\mathrm{ng} \mathrm{g}^{-1}$ )

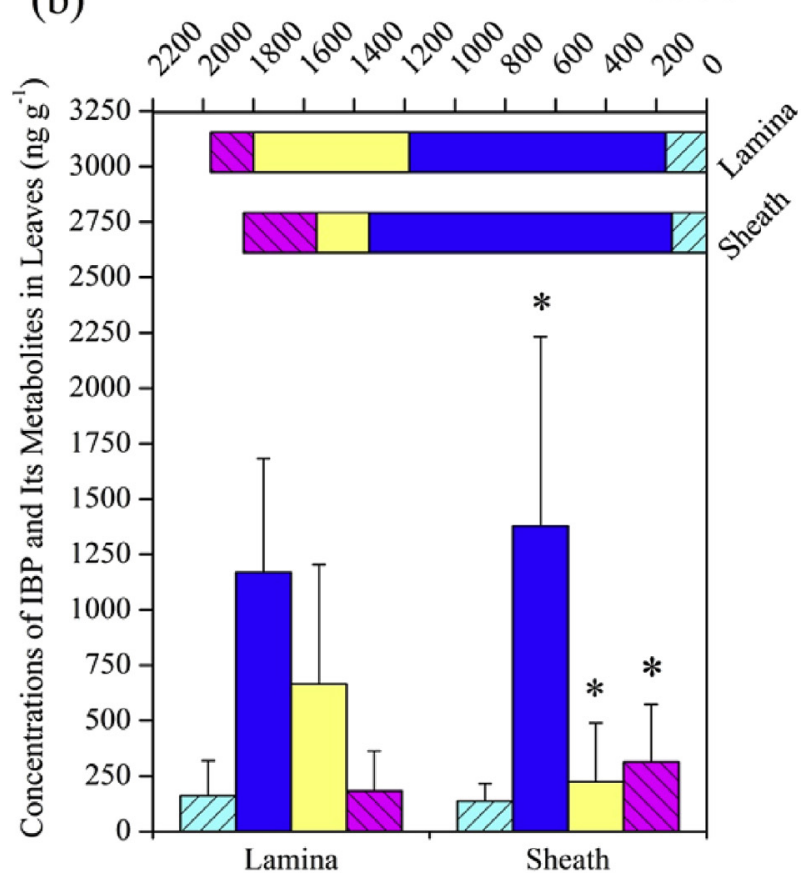

Fig. 5. Mean concentrations of ibuprofen (IBP), ibuprofen carboxylic acid (CBX IBP), 2hydroxy ibuprofen (2-OH IBP) and 1-hydroxy ibuprofen (1-OH IBP) in the lamina and sheath tissues of Typha angustifolia collected at $1 / 3 \mathrm{~L}(\mathrm{a})$ and $2 / 3 \mathrm{~L}(\mathrm{~b})$ in the planted bed. $1 / 3 \mathrm{~L}$ and $2 / 3 \mathrm{~L}$ are the locations at the $1 / 3$ length and $2 / 3$ length of the treatment section along the flow path, respectively. Sampling campaigns: $n=36$. The normalized IBP concentrations calculated from the concentrations of IBP metabolites are illustrated for the two sampling locations. * $p<0.05$ ( $t$-test).

$\mathrm{RCF}=\mathrm{W}+\mathrm{LcK}_{\mathrm{ow}}^{\mathrm{b}}$

where $\mathrm{W}$ is the water content of root tissue; $\mathrm{L}$ is the lipid content of root tissue; $\mathrm{c}$ and $\mathrm{b}$ are the coefficients to correct for difference between root tissue and octanol; $\mathrm{K}_{\mathrm{ow}}$ is octanol-water partition coefficient.

An empirical relationship between RCF and log $\mathrm{K}_{\mathrm{ow}}$ of nonionized chemicals has been established as shown in Eq. (2) (Briggs et al., 1982; Trapp, 2004).

$\mathrm{RCF}=0.82+0.03 \mathrm{~K}_{\mathrm{ow}}^{0.77}$

The $\log \mathrm{K}_{\mathrm{ow}}$ values of IBP, CBX IBP, 2-OH IBP and 1-OH IBP are 3.97, 2.78, 2.37 and 2.69, respectively (Ferrando-Climent et al., 2012). Thus, the root concentrations of IBP, 2-OH IBP and 1-OH IBP at $1 / 3 \mathrm{~L}$ in the planted bed were calculated at $81.4,9.1$ and $1.1 \mathrm{ng} \mathrm{g}^{-1}$, respectively, while $52.5,15.7$, and $1.2 \mathrm{ng} \mathrm{g}^{-1}$ at $2 / 3 \mathrm{~L}$. The root concentration of CBX IBP could not be estimated due to its low frequency of detection in the water. Apparently, IBP had the tendency to be taken up by the roots of Typha angustifolia but the root uptakes of its metabolites are to a low extent or negligible.

It is noted that the $\mathrm{pH}$ values of interstitial water within the planted bed (Table $\mathrm{S} 2$ ) were higher than the $\mathrm{pK}_{\mathrm{a}}$ values of IBP, CBX IBP, 2-OH IBP and 1-OH IBP (4.91, 3.97, 4.63 and 4.55, respectively) (Ferrando-Climent et al., 2012). The target compounds existed mainly in their negatively ionic forms with relatively lower hydrophobicity compared to their nonionic forms (Goldstein et al., 2014). The calculated results obtained from Eq. (2) may be therefore overestimated.

To further elaborate the phytoextraction process of IBP by Typha angustifolia and the mass balance of IBP in HSSF-CWs, parallel HSSF-CW systems are proposed for further study, which provide a possibility to measure root samples periodically.

\subsection{Phytotransformation}

As the root uptake of IBP metabolites was limited (Section 4.1), the great accumulation of IBP metabolites in the leaves of Typha angustifolia (Fig. 5) indicates the occurrence of phytotransformation of IBP in the plant tissues. According to the general detoxification process of organic pollutants in plants (Pilon-Smits, 2005), the phytotransformation of IBP to carboxylated (CBX IBP) and hydroxylated (2-OH IBP and 1-OH IBP) products was likely involved in the catalytic actions of carboxylesterases and monooxygenases. Besides, the activities of endophytic microorganisms might also be involved in the phytotransformation of IBP, but the contribution is considered to be at a low extent. One reason is attributable to the defense characteristics of plants to protect against microbial pathogens (Robert and Friml, 2009). Another interpretation is the relatively high concentration of CBX IBP in the leaf tissues (Fig. 5). The fast biodegradation rate of CBX IBP observed in certain biological treatment systems (Ferrando-Climent et al., 2012; Weigel et al., 2004; Winkler et al., 2001) suggests the high biodegradability of CBX IBP. Such a characteristic of CBX IBP would be likely to result in a low level of CBX IBP in the leaves if there were abundant endophytic microorganisms.

As reviewed by Pilon-Smits (2005), the transformation products of organic pollutants in plant leaves normally could be conjugated with glutathione or glucose in the cytosol under the catalysis of glutathione-S-transferases or glucosyltransferases, respectively, followed by compartmentation in the vacuole or the apoplast of leaf cells. In this study, it is observed that CBX IBP, 2-OH IBP and 1-OH IBP distributed unevenly in the sheath and lamina tissues of Typha angustifolia (Fig. 5). Such a phenomenon was most probably due to that different IBP metabolites were conjugated and compartmentized at different leaf tissues. In detail, 2-OH IBP tended to be conjugated and compartmentized in the sheath tissues, while CBX IBP and 1-OH IBP were likely to get conjugation and compartmentation in the lamina tissues.

Such information indicates that certain enzymes and cellular 


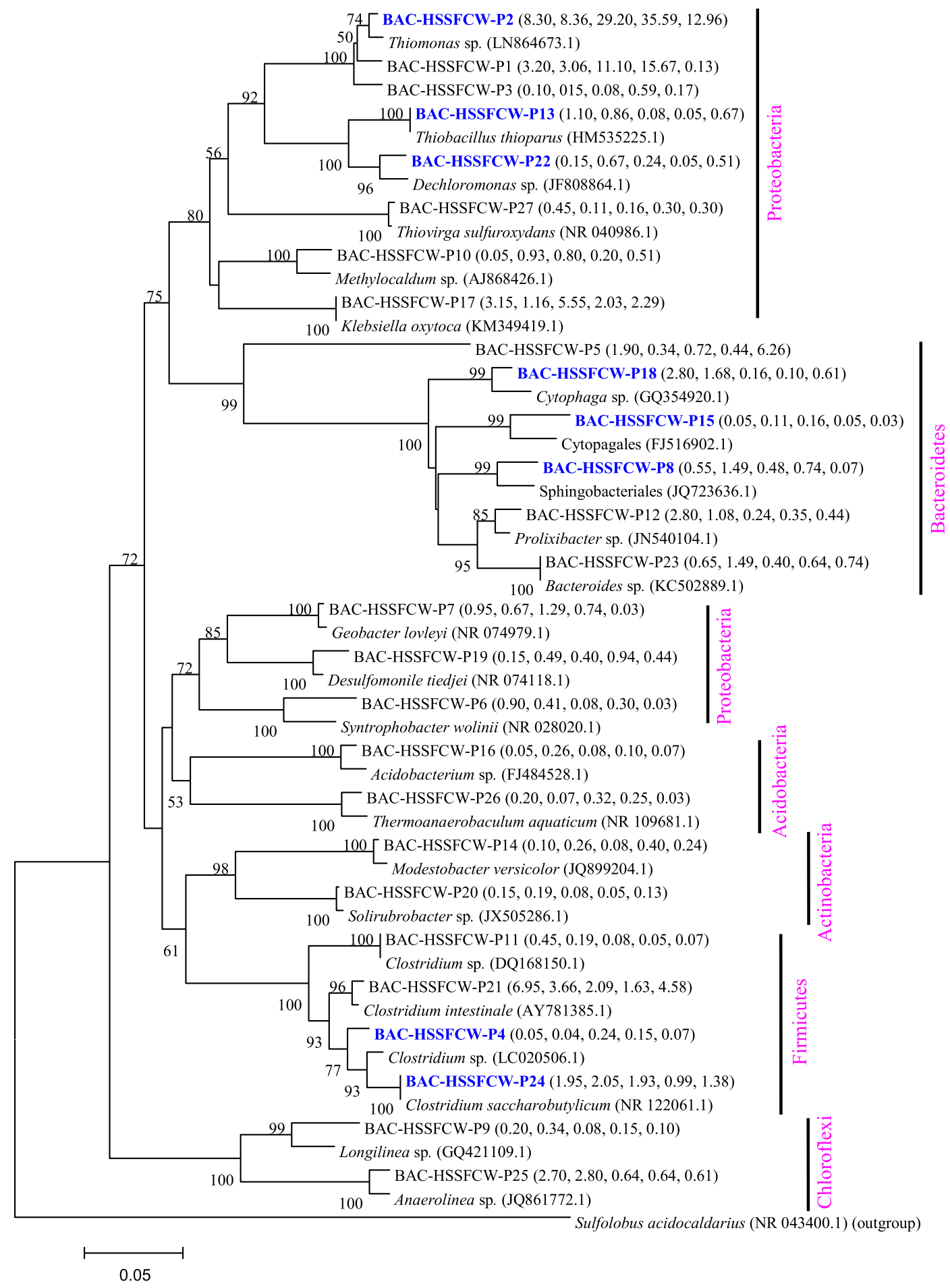

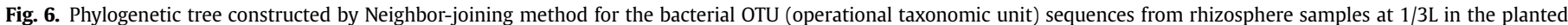

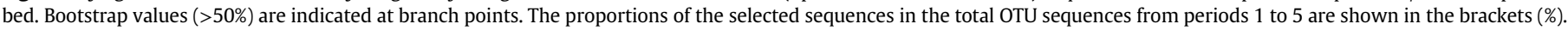
$1 / 3 \mathrm{~L}$ is the location at the $1 / 3$ length of the treatment section along the flow path.

components in the leaf tissues of Typha angustifolia are strongly related to IBP degradation, which requires further investigation. Especially, the conjugates of IBP metabolites in the tissues of Typha angustifolia could be a focus of concern.

\subsection{Rhizodegradation}

In our previous work ( $\mathrm{Li}$ et al., 2016), the probable bacteria relevant to the cometabolic and metabolic degradation of IBP in the HSSF-CW were assessed. In this study, we focused on the rhizosphere bacteria that were, most possibly, responsible for the rhizodegradation of IBP. In consideration of the continuous removal of IBP along the flow path over the long-term operation, the eight rhizosphere bacteria that existed at both sampling locations around $1 / 3 \mathrm{~L}$ and $2 / 3 \mathrm{~L}$ throughout the sampling periods (screened from the phylogenetic trees in Section 3.4) were analyzed to identify the 


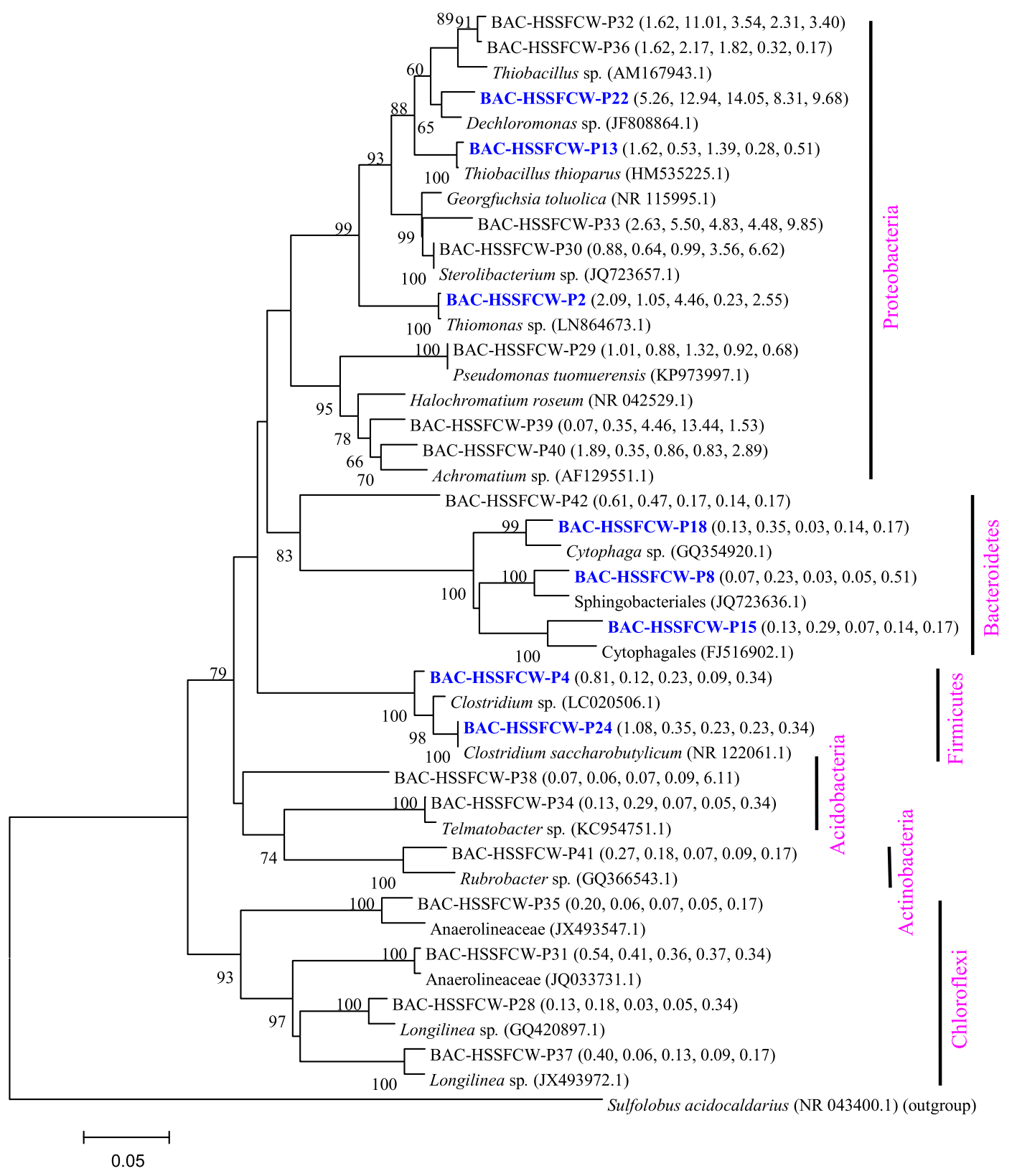

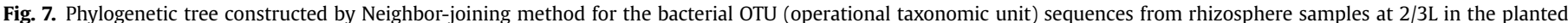

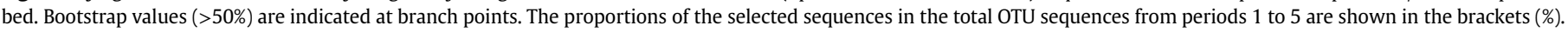
$2 / 3 \mathrm{~L}$ is the location at the $2 / 3$ length of the treatment section along the flow path.

ones most capable of degrading IBP in the rhizosphere of Typha angustifolia.

Among the eight bacteria, Thiomonas sp. and Thiobacillus sp. (e.g. Thiobacillus thioparus) in the same class Betaproteobacteria have been reported as the bacteria able to oxidize sulfide but not capable of degrading aromatic compounds (García-de-la-Fuente et al., 2011; Hallberg and Johnson, 2005; Luo et al., 2013; Ramírez et al., 2009). Dechloromonas sp., one type of chlorate-reducing bacteria (Nor et al., 2011; Schwarz et al., 2012), suggests a possible ability to degrade IBP although it has not been related to the degradation of aromatic compounds. This species was also found in our previous work (Li et al., 2016) showing a probability of cometabolically degrading IBP. Clostridium sp. (e.g. Clostridium saccharobutylicum) is able to degrade glucose, starch or xylose through fermentation processes (Berezina et al., 2009; Noparat et al., 2011; Saint-Amans et al., 2001; Zhao et al., 2011) and thus is likely to anaerobically degrade ibuprofen. This species was also thought to contribute to the cometabolism of IBP (Li et al., 2016). Besides, the Bacteroidetes bacteria such as the order Sphingobacteriales and the Cytophaga sp. in the order Cytophagales possess the capability to decompose aromatic compounds by aerobic degradation or anaerobic processes (Chang et al., 2007; Nakagawa et al., 2002; Phelps et al., 1998; Xue et al., 2016; Zhang et al., 2013). These bacteria detected in this study were plausibly relevant to the rhizodegradation of IBP.

To date, there are only limited reported studies on the bacteria actively involved in the microbial degradation of IBP, and even less on the bacteria responsible for the rhizodegradation of IBP. Murdoch and Hay (2013) found a Sphingomonas sp. strain in the phylum Proteobacteria capable of degrading IBP to yield catechols under aerobic conditions. They also isolated a bacterium in the 
genus Variovorax within the $\beta$-proteobacteria from activated sludge possible for the metabolism of IBP via a trihydroxyiibuprofen pathway (Murdoch and Hay, 2015). Almeida et al. (2013) investigated the Patulibacter sp. strain I11 isolated from activated sludge to identify the optimal proteins responsible for IBP degradation. The above reported bacteria able to degrade IBP were not observed in this study. The finding of the Dechloromonas sp., the Clostridium sp. (e.g. Clostridium saccharobutylicum), the order Sphingobacteriales, and the Cytophaga sp. in the order Cytophagales in this study is of pioneer significance to reveal a possible rhizodegradaiton community of IBP in the rhizosphere of Typha angustifolia. It possesses a probability to cultivate certain species of these bacteria to study the relationship between the IBP biodegradation pathway and the rhizosphere properties of Typha angustifolia.

\section{Conclusions}

The present study investigated the removal mechanisms of IBP associated with plants in a HSSF-CW and the findings provided an insight into the processes of phytoextraction, phytotransformation and rhizodegradation of IBP by Typha angustifolia.

- Detection of IBP in the leaves of Typha angustifolia with an even distribution in the lamina and sheath tissues reveals that IBP had been taken up by the roots of Typha angustifolia followed by a translocation from the roots to leaves and an accumulation in leaf tissues, namely, the phytoextraction process of IBP.

- The metabolites of IBP including CBX IBP, 2-OH IBP and 1-OH IBP accumulated in the leaves of Typha angustifolia and distributed unevenly in the lamina and sheath, indicating the phytotransformation of IBP in the plant tissues.

- The analysis of 454 high-throughput pyrosequencing for the bacterial 16S rRNA gene isolated from the samples in the rhizosphere of Typha angustifolia suggests the most probable bacteria strongly responsible for the rhizodegradation of IBP such as the Dechloromonas sp., the Clostridium sp. (e.g. Clostridium saccharobutylicum), the order Sphingobacteriales, and the Cytophaga sp. in the order Cytophagales.

\section{Acknowledgements}

This study was financially supported through in-house project funds by the Maritime Research Centre, School of Civil and Environmental Engineering, Advanced Environmental Biotechnology Centre, and Nanyang Environment and Water Research Institute, Nanyang Technological University, Singapore. The author Guibing Zhu gratefully acknowledges the support of National Natural Science Foundation of China (No. 41322012) and Humboldt Research Fellowship (1152633).

\section{Appendix A. Supplementary data}

Supplementary data related to this article can be found at http:// dx.doi.org/10.1016/j.watres.2016.06.049.

\section{References}

Almeida, B., Kjeldal, H., Lolas, I., Knudsen, A.D., Carvalho, G., Nielsen, K.L., Barreto Crespo, M.T., Stensballe, A., Nielsen, J.L., 2013. Quantitative proteomic analysis of ibuprofen-degrading Patulibacter sp. strain I11. Biodegradation 24 (5), 615-630. http://dx.doi.org/10.1007/s10532-012-9610-5.

Babatunde, A.O., Zhao, Y.Q., O’Neill, M., O'Sullivan, B., 2008. Constructed wetlands for environmental pollution control: a review of developments, research and practice in Ireland. Environ. Int. 34 (1), 116-126. http://dx.doi.org/10.1016/ j.envint.2007.06.013.

Berezina, O.V., Brandt, A., Yarotsky, S., Schwarz, W.H., Zverlov, V.V., 2009. Isolation of a new butanol-producing Clostridium strain: high level of hemicellulosic activity and structure of solventogenesis genes of a new Clostridium saccharobutylicum isolate. Syst. Appl. Microbiol. 32 (7), 449-459. http://dx.doi.org/ 10.1016/j.syapm.2009.07.005.

Briggs, G.G., Bromilow, R.H., Evans, A.A., 1982. Relationship between lipophilicity and root uptake and translocation of non-ionised chemicials by Barley. Pestic. Sci. 13 (5), 495-504. http://dx.doi.org/10.1002/ps.2780130506.

Chang, B.V., Chiang, B.W., Yuan, S.Y., 2007. Biodegradation of nonylphenol in soil. Chemosphere $66 \quad$ (10), 1857-1862. http://dx.doi.org/10.1016/ j.chemosphere.2006.08.029.

Cizmas, L., Sharma, V.K., Gray, C.M., McDonald, T.J., 2015. Pharmaceuticals and personal care products in waters: occurrence, toxicity, and risk. Environ. Chem. Lett. 13 (4), 381-394. http://dx.doi.org/10.1007/s10311-015-0524-4.

Corcoran, J., Winter, M.J., Tyler, C.R., 2010. Pharmaceuticals in the aquatic environment: a critical review of the evidence for health effects in fish. Crit. Rev. Toxicol. 40 (4), 287-304. http://dx.doi.org/10.3109/10408440903373590.

David, A., Pancharatna, K., 2009. Developmental anomalies induced by a nonselective COX inhibitor (ibuprofen) in zebrafish (Danio rerio). Environ. Toxicol. Pharmacol. 27 (3), 390-395. http://dx.doi.org/10.1016/j.etap.2009.01.002.

Dordio, A.V., Belo, M., Martins Teixeira, D., Palace Carvalho, A.J., Dias, C.M.B., Picó, Y., Pinto, A.P., 2011. Evaluation of carbamazepine uptake and metabolization by Typha spp., a plant with potential use in phytotreatment. Bioresour. Technol. 102 (17), 7827-7834. http://dx.doi.org/10.1016/j.biortech.2011.06.050.

Fent, K., Weston, A.A., Caminada, D., 2006. Ecotoxicology of human pharmaceuticals. Aquat. Toxicol. 76 (2), 122-159. http://dx.doi.org/10.1016/ j.aquatox.2005.09.009.

Ferrando-Climent, L., Collado, N., Buttiglieri, G., Gros, M., Rodriguez-Roda, I., Rodriguez-Mozaz, S., Barceló, D., 2012. Comprehensive study of ibuprofen and its metabolites in activated sludge batch experiments and aquatic environment. Sci. Total Environ. 438, 404-413. http://dx.doi.org/10.1016/ j.scitotenv.2012.08.073.

Flippin, J.L., Huggett, D., Foran, C.M., 2007. Changes in the timing of reproduction following chronic exposure to ibuprofen in Japanese medaka, Oryzias latipes. Aquat. Toxicol. 81 (1), 73-78. http://dx.doi.org/10.1016/j.aquatox.2006.11.002.

García-de-la-Fuente, R. Cuesta, G, Sanchís-Jiménez, E, Botella, $S$, Abad, M. Fornes, F., 2011. Bacteria involved in sulfur amendment oxidation and acidification processes of alkaline 'alperujo' compost. Bioresour. Technol. 102 (2), 1481-1488. http://dx.doi.org/10.1016/j.biortech.2010.09.103.

Goldstein, M., Shenker, M., Chefetz, B., 2014. Insights into the uptake processes of wastewater-borne pharmaceuticals by vegetables. Environ. Sci. Technol. 48 (10), 5593-5600. http://dx.doi.org/10.1021/es5008615.

Hallberg, K.B., Johnson, D.B., 2005. Microbiology of a wetland ecosystem constructed to remediate mine drainage from a heavy metal mine. Sci. Total Environ. 338 (1-2), 53-66. http://dx.doi.org/10.1016/j.scitotenv.2004.09.005.

Li, Y., Zhu, G., Ng, W.J., Tan, S.K., 2014. A review on removing pharmaceutical contaminants from wastewater by constructed wetlands: design, performance and mechanism. Sci. Total Environ. 468-469, 908-932. http://dx.doi.org/10.1016/ j.scitotenv.2013.09.018.

Li, Y., Tan, S.K., 2015. Performance of constructed wetland for the removal of highloaded ibuprofen from wastewater. Int. J. Environ. Sustain. 11 (2).

Li, Y., Wu, B., Zhu, G., Liu, Y., Ng, W.J., Appan, A., Tan, S.K., 2016. High-throughput pyrosequencing analysis of bacteria relevant to cometabolic and metabolic degradation of ibuprofen in horizontal subsurface flow constructed wetlands. Sci. Total Environ. 562, 604-613. http://dx.doi.org/10.1016/ j.scitotenv.2016.04.020.

Liu, J., Lu, G., Xie, Z., Zhang, Z., Li, S., Yan, Z., 2015. Occurrence, bioaccumulation and risk assessment of lipophilic pharmaceutically active compounds in the downstream rivers of sewage treatment plants. Sci. Total Environ. 511, 54-62. http://dx.doi.org/10.1016/j.scitotenv.2014.12.033.

Luo, J., Tian, G., Lin, W., 2013. Enrichment, isolation and identification of sulfuroxidizing bacteria from sulfide removing bioreactor. J. Environ. Sci. 25 (7), 1393-1399. http://dx.doi.org/10.1016/S1001-0742(12)60179-X.

Luo, Y., Guo, W., Ngo, H.H., Nghiem, L.D., Hai, F.I., Zhang, J., Liang, S., Wang, X.C., 2014. A review on the occurrence of micropollutants in the aquatic environment and their fate and removal during wastewater treatment. Sci. Total Environ. 473-474, 619-641. http://dx.doi.org/10.1016/j.scitotenv.2013.12.065.

Murdoch, R.W., Hay, A.G., 2013. Genetic and chemical characterization of ibuprofen degradation by Sphingomonas Ibu-2. Microbiology 159 (PART3), 621-632. http://dx.doi.org/10.1099/mic.0.062273-0.

Murdoch, R.W., Hay, A.G., 2015. The biotransformation of ibuprofen to trihydroxyibuprofen in activated sludge and by Variovorax Ibu-1. Biodegradation 26 (2), 105-113. http://dx.doi.org/10.1007/s10532-015-9719-4.

Nakagawa, T., Sato, S., Yamamoto, Y., Fukui, M., 2002. Successive changes in community structure of an ethylbenzene-degrading sulfate-reducing consortium. Water Res. 36 (11), 2813-2823. http://dx.doi.org/10.1016/S0043-1354(01) 00502-4.

Noparat, P., Prasertsan, P., O-Thong, S., 2011. Isolation and characterization of high hydrogen-producing strain Clostridium beijerinckii PS-3 from fermented oil palm sap. Int. J. Hydrogen Energy 36 (21), 14086-14092. http://dx.doi.org/ 10.1016/j.ijhydene.2011.04.143.

Nor, S.J., Lee, S.H., Cho, K.-S., Cha, D.K., Lee, K.I., Ryu, H.W., 2011. Microbial treatment of high-strength perchlorate wastewater. Bioresour. Technol. 102 (2), 835-841. http://dx.doi.org/10.1016/j.biortech.2010.08.127.

Phelps, C.D., Kerkhof, L.J., Young, L.Y., 1998. Molecular characterization of a sulfatereducing consortium which mineralizes benzene. FEMS Microbiol. Ecol. 27 (3), 269-279. http://dx.doi.org/10.1016/S0168-6496(98)00073-7. 
Pilon-Smits, E., 2005. Phytoremediation. Annu. Rev. Plant Biol. 56, 15-39. http:// dx.doi.org/10.1146/annurev.arplant.56.032604.144214.

Ramírez, M., Gómez, J.M., Aroca, G., Cantero, D., 2009. Removal of hydrogen sulfide by immobilized Thiobacillus thioparus in a biotrickling filter packed with polyurethane foam. Bioresour. Technol. 100 (21), 4989-4995. http://dx.doi.org/ 10.1016/j.biortech.2009.05.022.

Robert, H.S., Friml, J., 2009. Auxin and other signals on the move in plants. Nat. Chem. Biol. 5 (5), 325-332. http://dx.doi.org/10.1038/nchembio.170.

Saint-Amans, S., Girbal, L., Andrade, J., Ahrens, K., Soucaille, P., 2001. Regulation of carbon and electron flow in Clostridium butyricum VPI 3266 grown on glucoseglycerol mixtures. J. Bacteriol. 183 (5), 1748-1754. http://dx.doi.org/10.1128/ JB.183.5.1748-1754.2001.

Saravanan, M., Devi, K.U., Malarvizhi, A., Ramesh, M., 2012. Effects of Ibuprofen on hematological, biochemical and enzymological parameters of blood in an Indian major carp, Cirrhinus mrigala. Environ. Toxicol. Pharmacol. 34 (1), 14-22. http://dx.doi.org/10.1016/j.etap.2012.02.005.

Schwarz, A.O., Urrutia, H., Vidal, J.M., Pérez, N., 2012. Chlorate reduction capacity and characterisation of chlorate reducing bacteria communities in sediments of the rio Cruces wetland in southern Chile. Water Res. 46 (10), 3283-3292. http://dx.doi.org/10.1016/j.watres.2012.03.046.

Trapp, S., Matthies, M., 1995. Generic one-compartment model for uptake of organic chemicals by foliar vegetation. Environ. Sci. Technol. 29 (9), 2333-2338. http:// dx.doi.org/10.1021/es00009a027.

Trapp, S., 2004. Plant uptake and transport models for neutral and ionic chemicals. Environ. Sci. Pollut. Res. 11 (1), 33-39. http://dx.doi.org/10.1065/ espr2003.08.169.

Verlicchi, P., Zambello, E., 2014. How efficient are constructed wetlands in removing pharmaceuticals from untreated and treated urban wastewaters? A review. Sci.
Total Environ. 470-471, 1281-1306. http://dx.doi.org/10.1016 j.scitotenv.2013.10.085.

Vymazal, J., 2011. Constructed wetlands for wastewater treatment: five decades of experience. Environ. Sci. Technol. 45 (1), 61-69. http://dx.doi.org/10.1021 es101403q.

Wang, L., Peng, Y., Nie, X., Pan, B., Ku, P., Bao, S., 2016. Gene response of CYP360A, CYP314, and GST and whole-organism changes in Daphnia magna exposed to ibuprofen. Comp. Biochem. Phys. C 179, 49-56. http://dx.doi.org/10.1016 j.cbpc.2015.08.010.

Weigel, S., Berger, U., Jensen, E., Kallenborn, R., Thoresen, H., Hühnerfuss, H., 2004 Determination of selected pharmaceuticals and caffeine in sewage and seawater from Tromsø/Norway with emphasis on ibuprofen and its metabolites. Chemosphere 56 (6), 583-592. http://dx.doi.org/10.1016 j.chemosphere.2004.04.015.

Winkler, M., Lawrence, J.R., Neu, T.R., 2001. Selective degradation of ibuprofen and clofibric acid in two model river biofilm systems. Water Res. 35 (13) 3197-3205. http://dx.doi.org/10.1016/S0043-1354(01)00026-4.

Xue, J., Zhang, Y., Liu, Y., Gamal El-Din, M., 2016. Treatment of oil sands processaffected water (OSPW) using a membrane bioreactor with a submerged flatsheet ceramic microfiltration membrane. Water Res. 88, 1-11. http:// dx.doi.org/10.1016/j.watres.2015.09.051.

Zhang, Y., Li, Y., Wang, L., Tang, Y., Chen, J., Hu, Y., Fu, X., Le, Y., 2013. Soil microbiological variability under different successional stages of the Chongming Dongtan wetland and its effect on soil organic carbon storage. Ecol. Eng. 52, 308-315. http://dx.doi.org/10.1016/j.ecoleng.2012.10.002.

Zhao, X., Xing, D., Fu, N., Liu, B., Ren, N., 2011. Hydrogen production by the newly isolated Clostridium beijerinckii RZF-1108. Bioresour. Technol. 102 (18) 8432-8436. http://dx.doi.org/10.1016/j.biortech.2011.02.086. 